\title{
The Influence of the Deposition Parameters on the Properties of Ni-Cu Deposition
}

\begin{abstract}
OANA CLAUDIA CIOBOTEA BARBU1,2, IOANA ALINA CIOBOTARU1*, FLORIN MIHAI BENGA ${ }^{1}$, DANUT IONEL VAIREANU1
'University Politehnica of Bucharest, Faculty of Applied Chemistry and Materials Science, 1-7 Polizu Str., 011061, Bucharest, Romania

${ }^{2}$ Geological Institute of Romania, 1 Caransebes Str., 01227, Bucharest, Romania

This paper discusses the properties of some Ni-Cu deposits obtained on a steel substrate, which may be employed as supercapacitor plates. In order to achieve plates with different properties, one has varied the parameters of the deposition process such as deposition time, current density and temperature. Scanning electron microscopy and dispersive energy spectrometry were employed for the determination of the structure and composition of the Ni-Cu deposits. The plates with the Ni-Cu deposits were used to create supercapacitors and their capacitance values were also determined.
\end{abstract}

Keywords: Ni-Cu deposits, scanning electron microscopy, capacitance measurements

Supercapacitors, also known as electrochemical capacitors or ultracapacitors, have been studied for more than 50 years. They are considered to be a potential application for energy storage in order to replace the conventional batteries [1-4]. One of the characteristics of the supercapacitors is that they can store a much higher amount of energy than the conventional capacitors. Generally, a supercapacitor consists of two electrode plates, the most employed electrodes being the porous ones, a dielectric separator and an electrolyte [5].

High dimensions and high surface area of the nanostructure provide easy diffusion paths and improved diffusivity, essential for supercapacitors in order to increase their performance, while low proportions offer good mechanical stability. Morphology plays an important role in defining the performance of an electrode [6], the two above mentioned properties being achieved by means of a foam deposition [7].

Significant progresses have been made in the last century regarding the supercapacitor plates reinforcement research. It consists of various materials such as polymers, metals, ceramics and glass [2]. A large number of supercapacitors have carbon-based reinforcement due to their high performance and high power density [8]. Research studies have been carried out on copper oxide obtained by chemical deposition [9], copper-based reinforcements deposited on steel in ionic liquids [10], nickel oxides reinforcements also obtained by chemical deposition [11] or sol-gel or electrostatic sputter deposition [1].

The properties of these deposits can be controlled by adjusting the working parameters such as deposition time, applied current density, chemical composition of electrolyte, temperature, etc. [12-14].

The aim of this paper is to characterize some Ni-Cu foams deposited on steel substrates that may be employed as supercapacitor plates. The structural characterization of the Ni-Cu foams was performed by scanning electron microscopy, dispersive energy spectrometry and the properties of the supercapacitors obtained were determined by measuring their capacitance.

\section{Experimental part}

Materials and methods

The deposition solution consists in a mixture of $0.5 \mathrm{M}$ CuSO $\cdot 5 \mathrm{H}_{2} \mathrm{O}$ (Sigma-Aldrich), $0.01 \mathrm{M} \mathrm{NiSO} \cdot 7 \mathrm{H}_{2} \mathrm{O}$ (Sigma-
Aldrich), $1.5 \mathrm{M} \mathrm{H}_{2} \mathrm{SO}_{4}$ (Chim Reactiv), $1 \mathrm{M} \mathrm{HCl}$ (Chim Reactiv) [4].

The electrochemical deposition cell consists of a steel plate electrode $\left(1.6 \mathrm{~cm}^{2}\right)$ used as cathode, a platinum mesh $\left(6 \mathrm{~cm}^{2}\right)$ used as anode and the above mentioned electrolyte solution. The steel plates used as substrate for the Ni-Cu deposits were polished with coarse (600) and fine emery paper (2000), cleaned and rinsed with distilled water and ethylic alcohol. After the cleaning process, the steel plate was dried and insulated on one side so that the deposition of the layers is performed only on one side.

In order to characterize the $\mathrm{Ni}-\mathrm{Cu}$ deposits, one has investigated some $\mathrm{Ni}-\mathrm{Cu}$ layers deposited on a steel substrate in different working conditions. The parameters varied during deposition are the current density $\left(1.3 \mathrm{~A} / \mathrm{cm}^{2}\right.$ and $\left.0.9 \mathrm{~A} / \mathrm{cm}^{2}\right)$, temperature $\left(20\right.$ and $40^{\circ} \mathrm{C}$ ) and deposition time ( 125 and $75 \mathrm{~s}$ ).

In order to depositat a constant value of the temperature, one has used a thermostated water bath fitted with a precision thermometer $20^{\circ} \mathrm{C}$ and, respectively, $40^{\circ} \mathrm{C}$. After the deposition of the layers, the plates were dried at $180 \pm 5^{\circ} \mathrm{C}$ in an oven for one hour.

For the capacitance measurements, one has used as a dielectric separator and a solid ionic electrolyte (a Nafion $117^{\circledR}$ membrane, DuPont).

Scanning electron microscopy (SEM) was employed in order to determine the morphology and structure of the deposition crystals.

Energy Dispersive Spectrometry (EDS) was employed in order to determine the composition of the deposited layers [15].

The analyses were performed with a ZEISS Merlin Gemini II scanning microscope with a resolution of 0.9 $\mathrm{nm}$. The detector used for the quantitative and semiquantitative analyses is an EDS OXFORD Instruments XMax 50 detector. The microscope is equipped with an electron gun, Schottky source, works at high vacuum and has a power up to $1000000 \mathrm{X}$.

In order to measure the capacitance, one has constructed a supercapacitor from two plates with the NiCu layers deposited in identical conditions and separated by a Nafion $117^{\circledR}$ membrane as dielectric separator. The value of the capacitance was measured using a LCRMultimeter 4095. 


\section{Results and discussions}

a) The structure of the Ni-Cu deposits

The structure of the Ni-Cu deposits was investigated using the scanning electron microscopy. The images recorded with the microscope were at magnifications situated in the range of $40 x$ and $14 k x$ to identify the formation and shape of the crystals. Ni-Cu deposits with different morphologies were obtained by varying the deposition working parameters.

In figures 1 and 2 are represented the electronic images of the Ni-Cu deposits obtained at a current density of 1.3A/ $\mathrm{cm}^{2}$ for 125 seconds at $20^{\circ} \mathrm{C}$ (fig. 1.) and at $40^{\circ} \mathrm{C}$ (fig. 2.). One maysee that the depositobtained at $20^{\circ} \mathrm{C}$ has a higher pore density than the one obtained at $40^{\circ} \mathrm{C}$. Also one may see, that at a low deposition temperature, the deposited layer is more compact and free from cracks than the one deposited at a higher temperature.

In figures 3 and 4 are shown the electronic images of $\mathrm{Ni}-\mathrm{Cu}$ deposits obtained at a current density of $1.3 \mathrm{~A} / \mathrm{cm}^{2}$ for $75 \mathrm{~s}$ at $20^{\circ} \mathrm{C}$ (fig. 3.) and at $40^{\circ} \mathrm{C}$ (fig. 4.). One may see

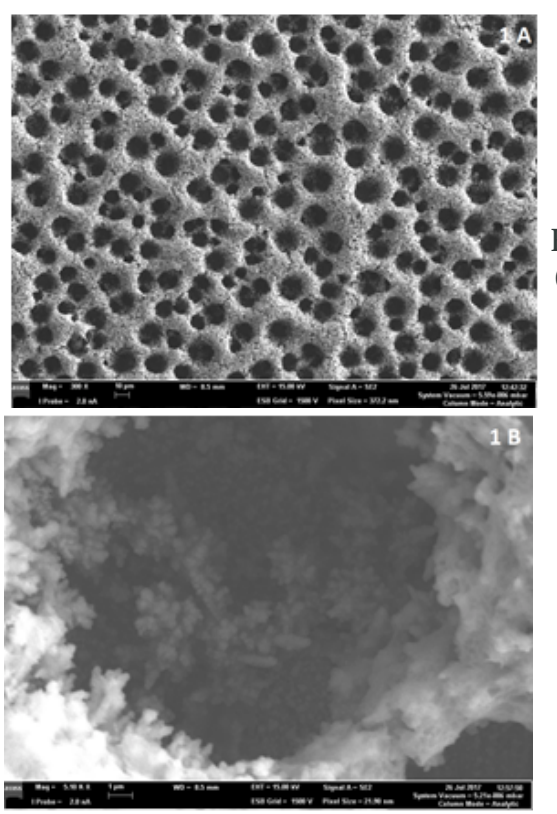

Fig. 1. SEM images of $\mathrm{Ni}-$ Cu deposits obtained at a current density of $1.3 \mathrm{~A} / \mathrm{cm}^{2}$ for 125 seconds at $20^{\circ} \mathrm{C}$, magnification 300x (a.) and $5000 \times(b$.
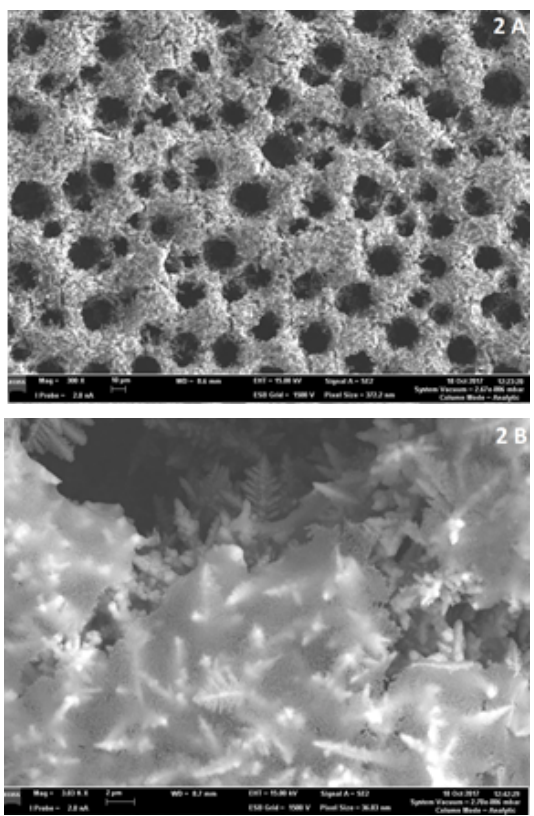

Fig. 2. SEM images of $\mathrm{Ni}$-Cu deposits obtained at a current density of $1.3 \mathrm{~A} / \mathrm{cm}^{2}$ for $125 \mathrm{~s}$ at $40^{\circ} \mathrm{C}$, magnification $300 \times$ (a.) and $3000 \times$ (b.)

that, as in the previous case, the deposit obtained at $20^{\circ} \mathrm{C}$ has a higher pore density than the one obtained at $40^{\circ} \mathrm{C}$, but the layer deposited at $40^{\circ} \mathrm{C}$ is thicker than the one achieved at $20^{\circ} \mathrm{C}$.

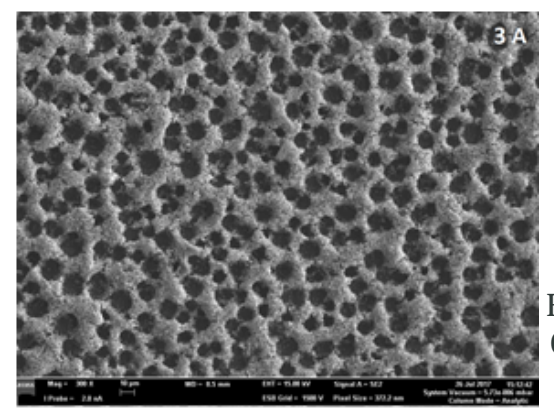

Fig. 3. SEM images of $\mathrm{Ni}-$ Cu deposits obtained at a current density of

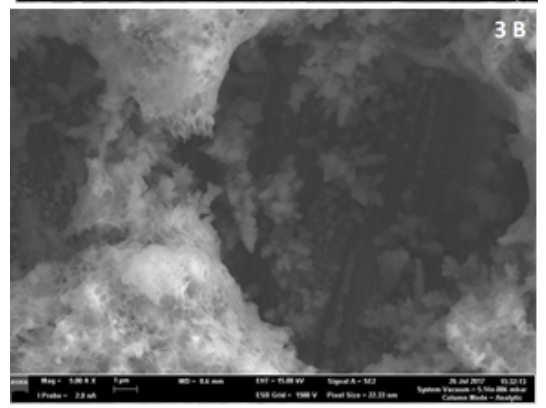
$3 \mathrm{~A} / \mathrm{cm}^{2}$ for 75 sat $20^{\circ} \mathrm{C}$ magnification $300 \times$ (a.) and $5000 x$ (b.)

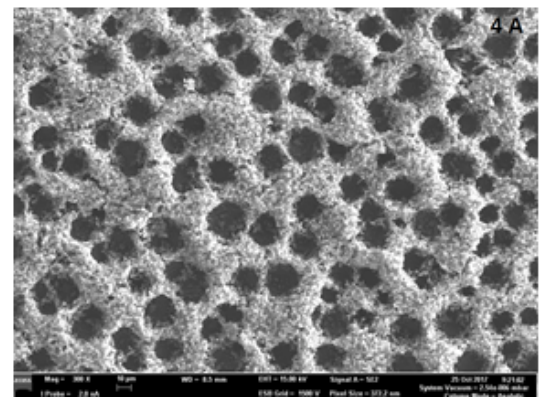

Fig. 4. SEM images of $\mathrm{Ni}$-Cu deposits obtained at a current density of $1.3 \mathrm{~A} / \mathrm{cm}^{2}$ for 75 seconds at $40^{\circ} \mathrm{C}$,

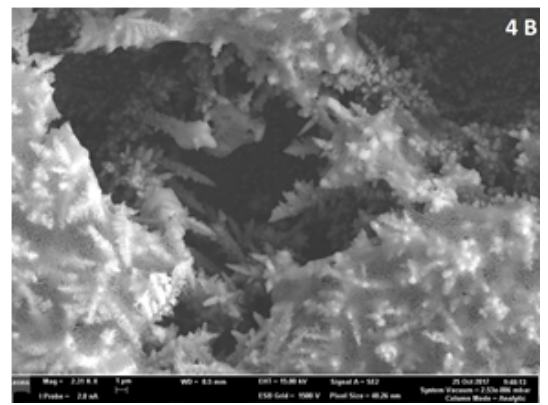
magnification $300 \times$ (a.) and 2000x (b.)
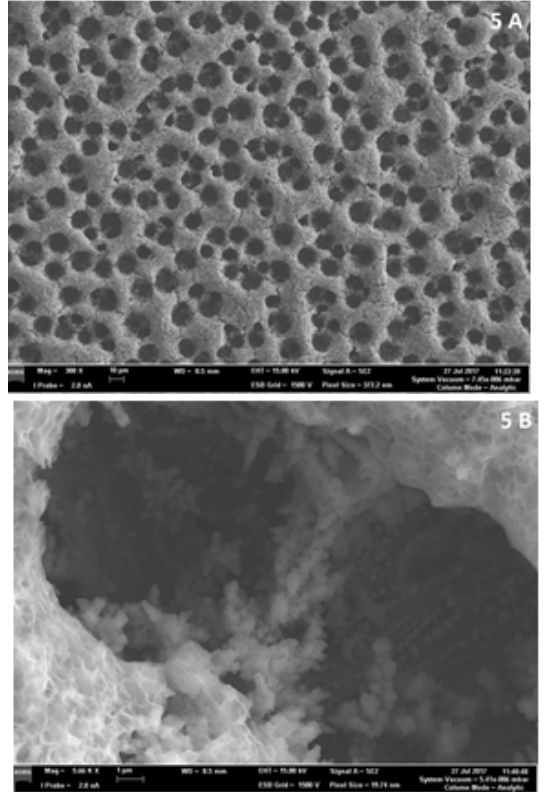

Fig. 5. SEM images of $\mathrm{Ni}-\mathrm{Cu}$ deposits obtained at a current density of $0.9 \mathrm{~A} / \mathrm{cm}^{2}$ for $125 \mathrm{~s}$ at $20^{\circ} \mathrm{C}$, magnification 300x (a.) and $5000 \mathrm{x}$ (b.)

The SEM images of the Ni-Cu deposits obtained at a current density of $0.9 \mathrm{~A} / \mathrm{cm}^{2}$ for $125 \mathrm{~s}$ at $20^{\circ} \mathrm{C}$ and $40^{\circ} \mathrm{C}$ are shown in figures 5 and, respectively 6 . One may see that the deposit obtained at $20^{\circ} \mathrm{C}$ has a higher pore density than 


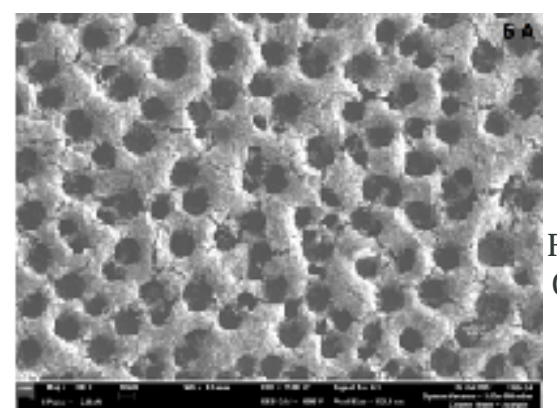

Fig. 6. SEM images of $\mathrm{Ni}-$ Cu deposits obtained at a current density of $0.9 \mathrm{~A} / \mathrm{cm}^{2}$ for 125 seconds at $40^{\circ} \mathrm{C}$

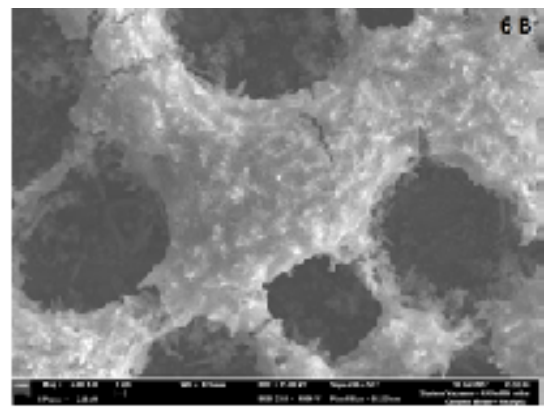
magnification 300x (a.) and 2000x (b.)

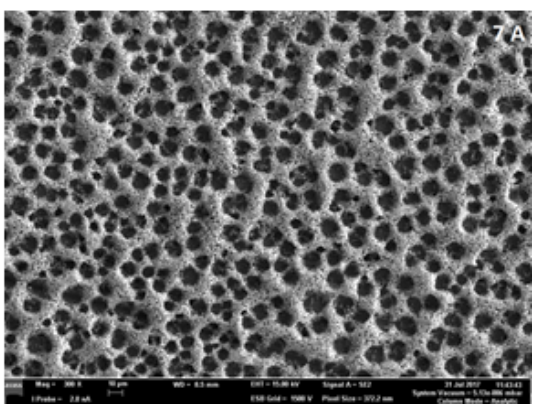

Fig. 7. SEM images of $\mathrm{Ni}$-Cu deposits obtained at a current density of $0.9 \mathrm{~A} / \mathrm{cm}^{2}$ for 75 seconds at $20^{\circ} \mathrm{C}$, magnification $300 \times($ a.) and $5000 \times(b$.

the one obtained at $40^{\circ} \mathrm{C}$. Another feature of both layers (deposited at 20 and $40^{\circ} \mathrm{C}$ ) is that they are thinner than the ones obtained at a higher current density $\left(1.3 \mathrm{~A} / \mathrm{cm}^{2}\right)$, but at the same deposition time (125 s).

In figures 7 and 8 are represented the electronic images of the Ni-Cu deposits obtained at a current density of $0.9 \mathrm{~A} /$ $\mathrm{cm}^{2}$ for $75 \mathrm{~s}$ at $20^{\circ} \mathrm{C}$ (fig. 7.) and at $40^{\circ} \mathrm{C}$ (fig. 8.). One may see that these layers of $\mathrm{Ni}-\mathrm{Cu}$ deposit are the thinnest deposits obtained. Also, at the layer deposited at $20^{\circ} \mathrm{C}$ has

\begin{tabular}{|c|c|c|c|c|c|}
\hline \multicolumn{2}{|c|}{ Deposition parameters } & \multicolumn{4}{|c|}{ Temperature, ${ }^{\circ} \mathrm{C}$} \\
\hline & & \multicolumn{2}{|c|}{$20^{\circ} \mathrm{C}$} & \multicolumn{2}{|c|}{$40^{\circ} \mathrm{C}$} \\
\hline $\begin{array}{l}\text { Current density, } \\
\qquad \mathrm{A} / \mathrm{cm}^{2}\end{array}$ & Time, s & $\begin{array}{c}\text { Average } \\
\text { pore diameter, } \\
\mu \mathrm{m}\end{array}$ & $\begin{array}{l}\text { Average bridge } \\
\text { thickness, } \mu \mathrm{m}\end{array}$ & $\begin{array}{c}\text { Average } \\
\text { pore diameter, } \\
\mu \mathrm{m}\end{array}$ & $\begin{array}{l}\text { Average bridge } \\
\text { thickness, } \mu \mathrm{m}\end{array}$ \\
\hline 1.3 & 125 & 10 & 20 & 19 & 34 \\
\hline 1.3 & 75 & 10 & 10 & 22 & 16 \\
\hline 0.9 & 125 & 9 & 12 & 16 & 22 \\
\hline 0.9 & 75 & 11 & 9 & 15 & 11 \\
\hline
\end{tabular}

Table 1

THE AVERAGE VALUES OF THE DIAMETER AND THICKNESS OF BRIDGES FORMED IN THE LAYERS 


\begin{tabular}{|c|c|c|c|c|c|}
\hline \multicolumn{2}{|c|}{ Deposition parameters } & \multicolumn{2}{|c|}{ Composition, $\%\left(20^{\circ} \mathrm{C}\right)$} & \multicolumn{2}{|c|}{ Composition, $\%\left(40^{\circ} \mathrm{C}\right)$} \\
\hline Current density, $\mathrm{A} / \mathrm{cm}^{2}$ & Time, s & $\mathrm{Cu}$ & $\mathrm{Ni}$ & $\mathrm{Cu}$ & $\mathrm{Ni}$ \\
\hline 1.3 & 125 & 42.34 & 14.85 & 46.81 & 14.47 \\
\hline 1.3 & 75 & 44.18 & 14.22 & 47.55 & 17.28 \\
\hline 0.9 & 125 & 48.15 & 10.61 & 39.09 & 4.64 \\
\hline 0.9 & 75 & 52.62 & 10.52 & 49.30 & 15.89 \\
\hline
\end{tabular}

Table 2

THE Ni-CU PUNCTUAL COMPOSITION IN THE TESTED LAYERS
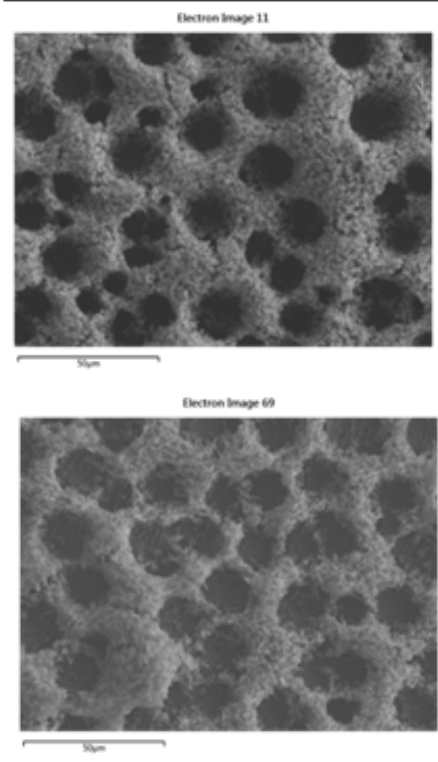

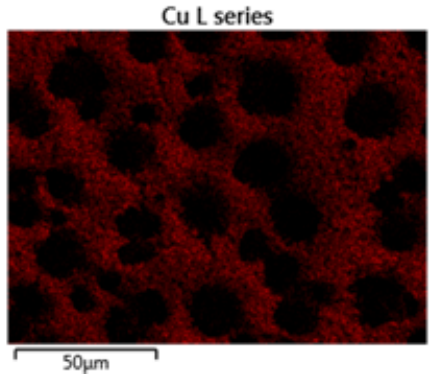

Cu L series

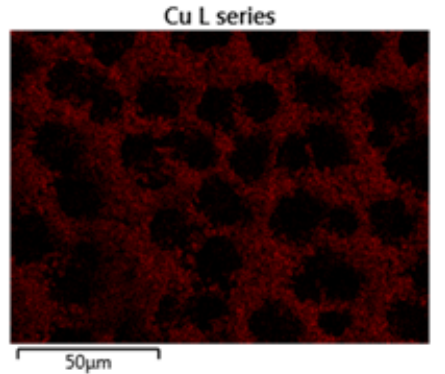

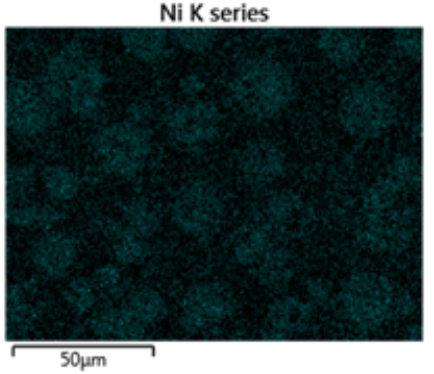

Ni K series

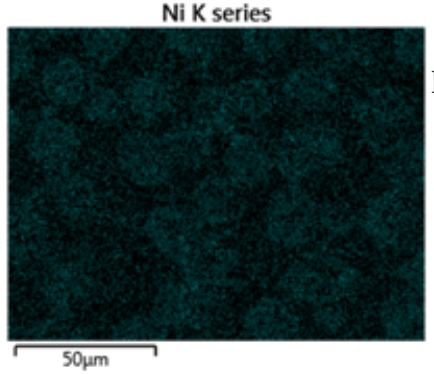

Fig. 9. The element distribution map of the $\mathrm{Ni}-\mathrm{Cu}$ deposit obtained at a current density of

$1.3 \mathrm{~A} / \mathrm{cm}^{2}$ for $125 \mathrm{~s}$ at $20^{\circ} \mathrm{C}$, magnification $800 x$

\begin{tabular}{|c|c|c|c|}
\hline \multicolumn{2}{|c|}{ Deposition parameters } & \multicolumn{2}{c|}{ Capacitance, $\mu \mathrm{F}$} \\
\hline Current density, $\mathbf{A} / \mathbf{c m}^{2}$ & Time, $\mathbf{s}$ & $\mathbf{2 0}{ }^{\circ} \mathrm{C}$ & $\mathbf{4 0}{ }^{\circ} \mathrm{C}$ \\
\hline 1.3 & 125 & 29.03 & 62.7 \\
\hline 1.3 & 75 & 36.03 & 27.6 \\
\hline 0.9 & 125 & 17.8 & 5.7 \\
\hline 0.9 & 75 & 41 & 19.6 \\
\hline
\end{tabular}

Table 3

THE VALUES OF THE CAPACITANCE percent up to $100 \%$ consisting of iron, carbon, oxygen, chlorine and sulphur in various percentages. It can be noticed that by varying the deposition parameters such as current density, time and temperature it is possible to achieve layers with different $\mathrm{Ni}$ and $\mathrm{Cu}$ content.

From table 2, one may see that by decreasing the current density and the deposition time, the concentration of $\mathrm{Cu}$ increases up to $52.62 \%$ (at $20^{\circ} \mathrm{C}$ ) and up to $49.30 \%$ (at $40^{\circ} \mathrm{C}$ ). Also, for the layers deposited at $20^{\circ} \mathrm{C}$ and at the same current density, one may see that the concentration of $\mathrm{Ni}$ shows a very small decrease with decreasing the time of deposition.

\section{c) Distribution map}

In order to determine the distribution of $\mathrm{Cu}$ and $\mathrm{Ni}$ in the deposited layers, one has recorded the element distribution maps. One may see that the element distribution is not influenced by the variation of the deposition process and that even though one may vary the current density or the deposition time, the nickel concentration is higher near the steel substrate than the one at the surface, where the concentration of copper is higher near the surface. In figures 9 and 10, the distribution maps of $\mathrm{Cu}$ (red) and $\mathrm{Ni}$ (turquoise) elements are shown.

\section{d) Capacitance measurements}

The values of the recorded capacitance for the tested supercapacitors are presented in table 3.

From table 3 , one may see that at a deposition temperature of $20^{\circ} \mathrm{C}$, with the decrease of the current density and the deposition time, when Ni concentration decreases and $\mathrm{Cu}$ increases, an increase in the capacitance value up to $41 \mu \mathrm{F}$ is noticed. For the deposition performed at $40^{\circ} \mathrm{C}$, Cu concentration increases, as does $\mathrm{Ni}$, leading to a decrease of the capacitance value, for the layers deposited at $1.3 \mathrm{~A} / \mathrm{cm}^{2}$, and to an increase of the capacitance for the layers deposited at a current density of $0.9 \mathrm{~A} / \mathrm{cm}^{2}$.

\section{Conclusions}

This paper shows the influence of the deposition parameters on the properties of the Ni-Cu deposits. One may see that by varying the current density, the time of the deposition and the temperature of the solution during the deposition, layers of Ni-Cu with different properties are achieved. For example, increasing the current density and the deposition time, one may see that the thickness of the deposited layer is increased. 
By varying the deposition parameters $n$, one may obtain different layers compositions, e.g. for the layers deposited at $20^{\circ} \mathrm{C}$, decreasing the current density and deposition time, the Ni concentration decreases from 14.85 to $10.52 \%$.

The Ni-Cu layers deposited have a porous structure with sizes in the range of 9 and $22 \mu \mathrm{m}$, depending on the employed parameters during the deposition process.

Acknowledgements: Special thanks go to Mr. Corneliu Andrei for providing the logistic support. Miss Oana Claudia Ciobotea-Barbu and Mr. Florin-Mihai Benga are financially supported by the Ministry of National Education of Romania. The SEM analysis was performed at MICROCOSMOS Laboratory from Geological Institute of Romania.

\section{References}

1. LOKHANDE, C.D., DUBAL, D.P., OH-J00, Curr. Appl. Phys., 11 2011, p. 255-270.

2. DEVIVIER, C., TAGLIAFERRI V., FROVALUSCI, F., UCCIARDELLO, N., Mater. Des., 85, 2015, p. 272-278.

3. MIRZAEIAN, M., OGWU, A.A., JIRANDEHI, H.F., AIDAROVA, S., OSPANOVA, Z., TSENDZUGHUL, N., Colloids Surf. A, 519, 2017, p. 223230.

4. EUGENIO S., SILVA T. M., CARMEZIM M. ., DUARTE R. G., MONTEMOR M. F., J. Appl. Electrochem., 44, 2014, p. 455-465.

5. RADUCAN E., Stocarea energiei electrice folosind noi dispozitive capacitive, PhD thesis summary, 2001, Galati, available on-line at https://www.arthra.ugal.ro:8443/bitstream/handle/123456789/2837/ Rezumat Teza_Raducan_Elena_2011.pdf?sequence $=1$ \&isAllowed $=\mathrm{y}$ 6. DAR, F..I, MOONOOSWAMY, K.R., ES-SOUNI, M., Nanoscale Res. Lett., 8/363, 2013, p.1-7.

7. TAPPAN, B.C., STEINER, S.A., LUTHER E.P., Nanoporous metal foams. Angew Chem Int Ed., 49, no. 27, 2010, p. 4544-4565.

8. WU, N., LOW, J., LIU, T., YU, J., CAO, S., Appl. Surf. Sci., 413, 2017, p. $35-40$.

9. DUBAL, D.P., DHAWALE, D.S., SALUNKHE, R.R., JAMDADE, V.S., LOKHANDE, C.D., J. Alloys Compd, 492, 2010, p. 26-30.

10. POPESCU, A.M.J., CONSTANTIN, V., OLTEANU, M., DEMIDENKO, 0., YANUSHKEVICH, K., Rev. Chim. (Bucharest), 62, no. 6, 2011, p. 627-632.

11. PATIL, U.M., SALUNKHE, R.R., GURAV, K.V., LOKHANDE, C.D., Appl. Surf. Sci., 255, 2008, p. 2603-2607.

12. GORANOVA, D., AVDEEV, G., RASHKOV, R., Surf. Coat. Technol., 240, 2014, p. 204-210.

13. PELLICER, E., VAREA, A., PANE, S., SIVARAMAN, K.M., NELSON, B.J., SURINACH, S., BARO, M.D., SORT, J., Surf. Coat. Technol., 205, 2011, p. 5285-5293.

14. GONZALEZ MERCADO, G.V., GONZALEZ, C.J., OLIVA, M.I., BRUNETTI, V., EIMER G. A., Procedia Mater. Sci., 8, 2015, p. 635-640. 15. NOVAC, R.I., SANDU A.V., VASILESCU, E., SANDU, I., Rev. Chim. (Bucharest), 65, no. 11, 2014, p. 1306-1309.

Manuscript received: 15.07 .2018 